Acta vet. scand. $1986,27,520-530$.

From the Institute of Hygiene and Microbiology, Royal Veterinary and Agricultural University, and the National Veterinary Laboratory, Copenhagen, Denmark.

\title{
HAEMAGGLUTINATING AND HYDROPHOBIC PROPERTIES OF CORYNEBACTERIUM (EUBACTERIUM) SUIS
}

\author{
By \\ Jens Laurits Larsen, Peter Høgh and Kari Hovind-Hougen
}

\begin{abstract}
LARSEN, J. L., P. HØGH and K. HOVIND-HOUGEN: Haemagglutinating and hydrophobic properties of Corynebacterium (Eubacterium) suis. Acta vet. scand. 1986, 27, 520-530. - Corynebacterium (Eubacterium) suis strains from boars and sows haemagglutinated erythrocytes of different animal species (calf, guinea pig, poultry, pig, and human).

The haemagglutination was mannose resistant (MR) and was neither inhibited by L-fucose nor D-galactose. The hydrophobicity measured by salt aggregation test $\left(0.1-0.9 \mathrm{~mol} / 1\left(\mathrm{NH}_{4}\right)_{2} \mathrm{SO}_{4}\right)$ and the hydrophobic interaction chromatography test $(90 \%$ retention in octyl sepharose) together with the haemagglutinating activity, indicated the presence of fimbriae on the bacteria. The haemagglutinating and hydrophobic properties were heat-sensitive $\left(60^{\circ} \mathrm{C}\right.$ for $\left.10 \mathrm{~min}\right)$ suggestive of the presence of a protein structure. Two types of fimbriation were demonstrated by electron microscopy. Fetuin and glycoprotein inhibited the haemagglutination, whereas porcine mucin was without any effect. These results indicate that branched glycoproteins might be important receptors for these fimbriae.

The pathogenic aspects of C. suis are discussed, based on recent acquired knowledge of the effect of other pyelonephritogenic bacteria.
\end{abstract}

fimbriae; haemagglutination; pyelonephritis.

The initial event in many infections is the attachment of the responsible organism to epithelial cells of mucous membranes in the host (Beachey 1981). Bacteria that do not adhere are removed by the secretions that bathe the mucosal surfaces (Mandel 1976). The adhesion is frequently mediated by surface structures called fimbriae (Duguid et al. 1955) or fibrillae (Jones 1977), which are defined according to their size and shape (Beachey 1981). The importance of fimbriae in pyelonephritogenic Escherichia coli is well-documented (van den Bosch et al. 1980, 
Källenius et al. 1983). Corynebacterium renale has also been found to possess such structures, and Honda \& Yanagawa (1975, 1978) suggested that adherence is the first stage in C. renale infections. Because the symptoms of the infections in sows caused by $\mathrm{C}$. suis are very similar to those caused by $\mathrm{C}$. renale in cattle, we decided to examine strains of C. suis for the presence of adhesins.

The hydrophobicity, together with the haemagglutinating activity, indicated that fimbriae were present on cells of C. suis. The fimbriae were visualized by electron microscopy.

\section{MATERIALS AND METHODS}

\section{Strains}

Seven strains of C. suis isolated from sows with cystitis and pyelonephritis, and 7 strains isolated from normal semen samples of boars, were used for this study (Table 1). The strains were isolated on Columbia agar (Oxoid CM311) with $5 \%$ citrated calf blood and $50 \mu \mathrm{g} / \mathrm{ml}$ of polymyxin B (Novo), after incubation at $37^{\circ} \mathrm{C}$ in an anaerobic atmosphere $\left(90 \% \mathrm{H}_{2}\right.$ and $\left.10 \% \mathrm{CO}_{2}\right)$ for 2-4 days. Colonies of $\mathrm{C}$. suis were identified by testing for presence of urease activity, and by indirect immunofluorescent antibody technique with sera from rabbits immunized with whole cell antigen from C. suis. The biochemical characteristics of cells from colonies which were positive in these two tests, were determined according to the methods described earlier (Larsen 1970 ).

\section{Bacterial suspensions}

The strains were cultured on thick BA plates (Brain-heart infusion agar (Difco) with $5 \%$ citrated calf blood) and incubated anaerobically at $37^{\circ} \mathrm{C}$ for 3 days. The cells were harvested, washed, and suspended in PBS, pH 7.4. The suspension was adjusted to an optical density of 0.4 as measured at $500 \mathrm{~nm}$, corresponding to approximately $3.1 \times 10^{10}$ bacteria $/ \mathrm{ml}$.

\section{Erythrocytes}

Calf, guinea pig, poultry, pig, and human erythrocytes were obtained by venipuncture of the animals. The erythrocytes were washed three times and finally suspended in PBS to a $3 \%$ (v/v) suspension. 


\section{Haemagglutination (HA) test}

The haemagglutination assay was performed by mixing 25 $\mu l$ of the bacteria suspension with $25 \mu$ of the erythrocyte suspension. For control, $25 \mu$ of the erythrocytes suspension was mixed with $25 \mu$ l PBS. The haemagglutination test was performed on a squared transparent glass plate on which multiple tests could be performed and read. The glass plate was continuously rocked during the procedure and was read after $2 \mathrm{~min}$ and 10 min, and evaluated as positive, weakly positive, or negative, according to the degree of agglutination of the erythrocytes.

\section{Haemagglutination inhibition}

One percent solutions of D-mannose, D-galactose, and L-fucose were used for the inhibition test. Twenty-five $\mu$ of a bacteria suspension was mixed with $25 \mu$ of the carbohydrate solution. Twenty-five $\mu l$ of an erythrocyte suspension was added after $30 \mathrm{~s}$. In the controls, the carbohydrate solution was replaced by $25 \mu$ of PBS. All the carbohydrates were tested simultaneously to evaluate the degree of inhibition. The cells were determined to be sensitive to a carbohydrate when agglutination was markedly reduced or absent.

Inhibition test with glycoconjugates and the effect on haemagglutination of protease

The following glycoconjugates were used: fetuin (Sigma F3004), mucin (Sigma M2378), and glycoprotein (Sigma G3259). All were used at a concentration of $6 \mathrm{mg} / \mathrm{ml}$. Trypsin (Difco) and pepsin (Nordisk Droge \& Kemikalie) were used for the protease pretreatment at a concentration of $100 \mathrm{mg} / \mathrm{ml}$ and 500 $\mu \mathrm{g} / \mathrm{ml}$. The tests were performed according to the procedure described by Lindal \& Smyth (1982).

\section{Influence of $\mathrm{pH}$ and temperature on the haemagglutination}

Isotonic phosphate buffers with $\mathrm{pH}$ values of $6.0,6.5,7.0,7.5$, and 8.0 were prepared and used for suspensions of the cells for the haemagglutination test. The preliminary studies indicated that buffers with $\mathrm{pH}$ of 7.0, 7.1, 7.2, 7.3, 7.4, and 7.5 should be used for a more exact determination of the optimum $\mathrm{pH}$ for haemagglutination. Samples of cells suspended in buffer were heated in a water bath for $10 \mathrm{~min}$ at $45^{\circ} \mathrm{C}, 60^{\circ} \mathrm{C}$, and $80^{\circ} \mathrm{C}$, respectively, before the $\mathrm{HA}$ tests were performed. 
Hydrophobic interaction chromatography (HIC) and Salt aggregation test (SAT)

The procedures described by Faris et al. (1982) were used for this test. Octyl Sepharose (Pharmacia) was used for the HIC test.

Adhesions of cells of C. suis to epithelial cells of the porcine bladder

Epithelial cells from the surface of the porcine bladder were prepared as described by Sato et al. (1982). Attached bacteria were counted on 50 viable bladder cells by light microscopy, at a magnification of $\times 1,000$.

\section{Electron microscopy}

Cells of strains 4,5 , and 8 were washed off the plates with approximately $2 \mathrm{ml}$ of SMC $(0.3 \%$ sucrose in redistilled water with $0.01 \mathrm{M} \mathrm{MgCl}_{2}$ and $0.01 \mathrm{M} \mathrm{CaCl}_{2}$ added) by gentle scraping with a glass triangle. The suspension was diluted to a suitable density and negatively stained by the multiple drop technique (Hovind-Hougen \& Birch-Andersen 1971). The stains used were $1 \%$ ammonium molybdate and $1 \%$ sodium silicium tungstate, both at $\mathrm{pH}$ 7.0.

Table 1. Haemagglutination activities of 14 strains of Corynebacterium suis.

\begin{tabular}{lllllll}
\hline \multirow{2}{*}{$\begin{array}{l}\text { Strain } \\
\text { No. }\end{array}$} & $\begin{array}{l}\text { Isolated } \\
\text { from }\end{array}$ & \multicolumn{5}{c}{ Erythrocytes from } \\
\cline { 3 - 7 } & & calf & guinea pig & poultry & pig & human \\
\hline 1 & Sow & + & + & - & - & - \\
2 & Sow & + & - & - & - & + \\
3 & Sow & + & + & + & - & + \\
4 & Sow & + & + & + & + & + \\
5 & Sow & + & + & + & - & + \\
6 & Sow & + & + & + & - & + \\
7 & Sow & - & - & - & - & - \\
8 & Boar & + & + & + & - & + \\
9 & Boar & + & + & + & + & + \\
10 & Boar & + & + & + & - & + \\
11 & Boar & + & + & + & + & + \\
12 & Boar & + & + & + & + & + \\
13 & Boar & + & + & + & - & + \\
14 & Boar & + & + & + & - & + \\
\hline
\end{tabular}

+ haemagglutination

- no reaction 


\section{RESULTS}

Haemagglutinating properties

Four strains agglutinated erythrocytes from all animal species tested, and 7 strains agglutinated erythrocytes from all species except the pig (Table 1). One strain isolated from a sow did not agglutinate any of the erythrocytes, and 2 others agglutinated only erythrocytes from calf and guinea pig, and from calf and man, respectively. All haemagglutinations were insensitive to D-mannose, D-galactose, and L-fucose. Yeast cells were not ag-

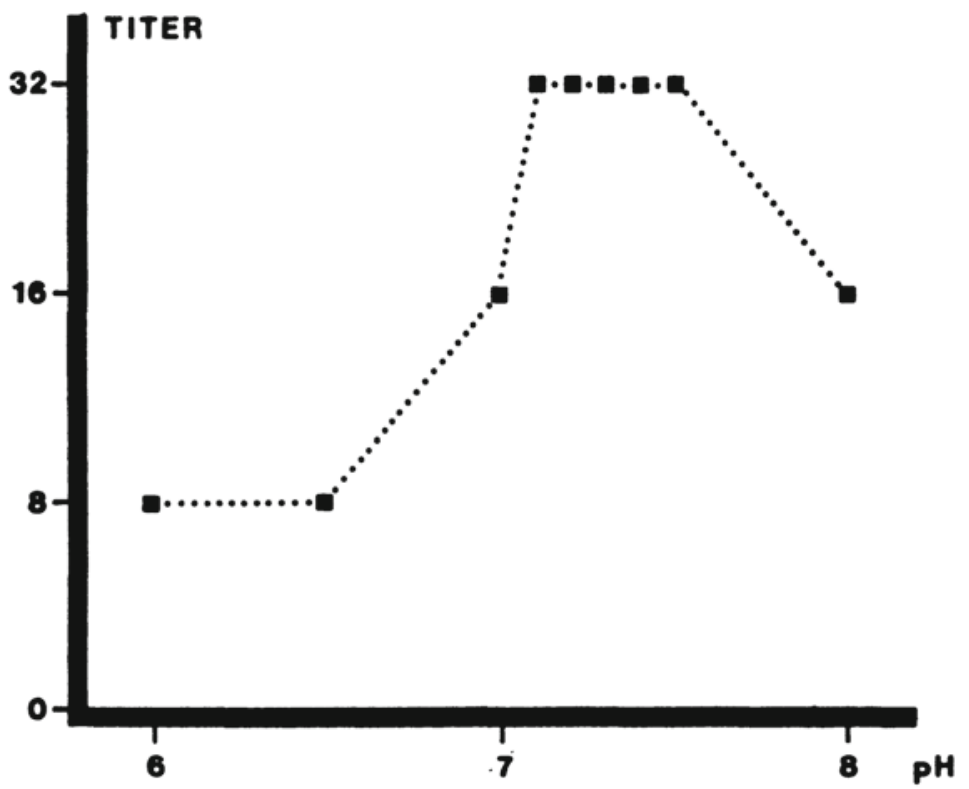

$\mathrm{Figure}$ 1. Influence of $\mathrm{pH}$ on the haemagglutinating titer (calf erythrocytes) of Corynebacterium suis (strain 4).

Figures $2-4$ all show fimbriated cells of Corynebacterium suis negatively stained with $1 \%$ ammonium molybdate (Figs. 2 and 4), and $1 \%$ sodium silicium tungstate (Fig. 3 ). The bar represents $100 \mathrm{~nm}$. Figure 2. Cell of strain 4 with rather flexible fimbriae (arrowheads). $\times 170,000$.

Figure 3. Cell of strain 5 with fimbriae which are somewhat thicker and more rigid (arrowheads) than those on strain 4 (Fig. 2). $\times 170,000$.

Figure 4. Cell of strain 8 with short, rigid (arrows) and longer, flexible (arrowheads) fimbriae. $\times 170,000$. 
Jens Laurits Larsen, Peter Hogh and Kari Hovind-Hougen: Haemagglutinating and Hydrophobic Properties of Corynebacterium (Eubacterium) Suis.
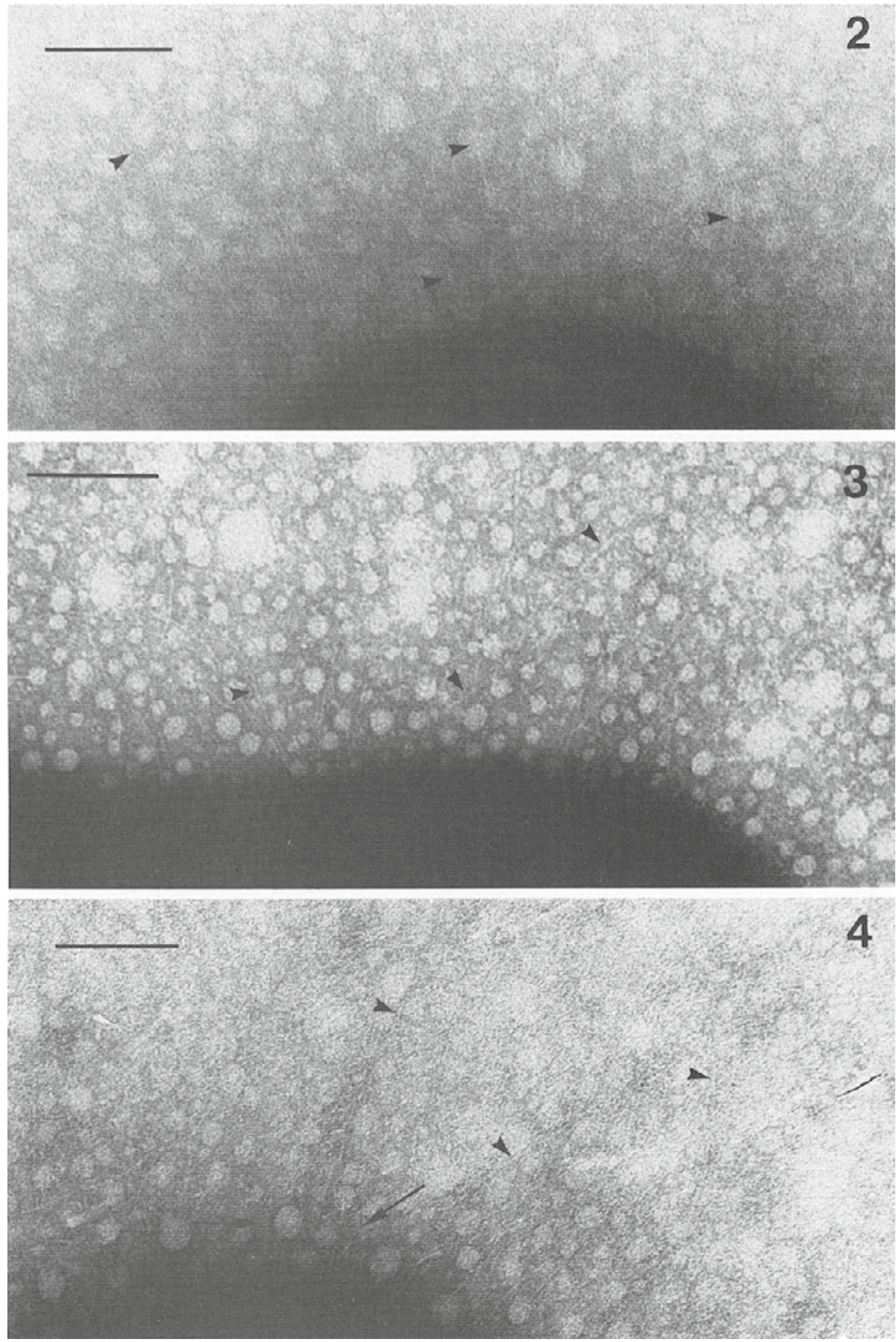

glutinated by any of the isolated strains. The haemagglutination titers of 2 strains are given in Table 2. By use of the principles of Duguid \& Gillies (1957), the minimum agglutinating dose (MAD) and the agglutinating power (AP) were found to range from $1.0 \times 10^{9}$ to $3.9 \times 10^{9}$ and from $2.6 \times 10^{1}$ to $1.0 \times 10^{2}$, respectively.

T a b l e 2. Haemagglutination titers of strains 4 and 12 to erythrocytes of different animal species.

\begin{tabular}{lcc}
\hline & \multicolumn{2}{c}{ Haemagglutination } \\
\cline { 2 - 3 } Species & $\begin{array}{l}\text { Strain } 4 \\
\text { (sows) }\end{array}$ & $\begin{array}{c}\text { Strain 12 } \\
\text { (boar) }\end{array}$ \\
\hline Calf & $32^{1}$ & 16 \\
Guinea pig & 32 & 8 \\
Poultry & 32 & 16 \\
Pig & 32 & 8 \\
Human & 8 & 8 \\
\hline
\end{tabular}

1 diluted 1:32

\section{Cell surface properties}

Haemagglutination was inhibited by the branched glycoproteins, while mucin did not influence this reaction (Table 3 ).

The haemagglutinating activity of $\mathrm{C}$. suis was insensitive to the action of the proteolytic enzymes trypsin and pepsin, and was heat sensitive.

Table 3. The adhesive properties of Corynebacterium suis.

\begin{tabular}{lcl}
\hline Test for adhesion & Reaction & Comments \\
\hline Haemagglutination & + & MRHA $^{1}$ \\
HIC $^{2}$ & + & $90 \%$ \\
SAT $^{3}$ & + & $0.1-0.9$ mol $/ 1\left(\mathrm{NH}_{4}\right)_{2} \mathrm{SO}_{4}$ \\
Bladder cells & + & $\begin{array}{l}\text { approx. } 23 \text { attached } \\
\text { bacteria per cell }\end{array}$ \\
Inhibition by & & $60^{\circ} \mathrm{C}$ for $10 \mathrm{~min}$ \\
$\quad$ Heat & + & $6 \mathrm{mg} / \mathrm{ml}$ \\
$\quad$ Fetuin & + & $6 \mathrm{mg} / \mathrm{ml}$ \\
$\quad$ Mucus & - & $6 \mathrm{mg} / \mathrm{ml}$ \\
$\quad$ Glycoprotein & + & 100 and $500 \mu \mathrm{g} / \mathrm{ml}$ \\
\hline
\end{tabular}

1 MRHA: Mannose resistant haemagglutination

2 HIC: Hydrophobic interaction chromatography

3 SAT: Salt aggregation test 
The haemagglutination titer was influenced by $\mathrm{pH}$, and the maximum agglutination took place when buffers with a $\mathrm{pH}$ of 7.0 - 8.0 were used (Fig. 1).

More than $90 \%$ of the bacteria that haemagglutinated the erythrocytes were adsorbed by the Octyl Sepharose columns (HIC positive).

Bacteria from all the strains tested formed aggregates when suspended in ammonium sulphate solutions of concentrations between 0.1 and $0.9 \mathrm{~mol} / \mathrm{l}$.

An average of 23 bacterial cells were attached to each bladder cell (range 16-34).

\section{Electron microscopy}

Cells of all strains were heavily fimbriated (Figs. 2-4). The fimbriae of strains 4 and 5 were approximately $1 \mathrm{~nm}$ thick and $0.05-0.3 \mu \mathrm{m}$ long. The fimbriae on strain 4 appeared to be rather flexible (Fig. 2), whereas the fimbriae on cells of strain 5 were more rigid (Fig. 3). Cells of strain 8 seemed to possess two kinds of fimbriae (Fig. 4). The cells of this strain were almost covered by very thin fimbriae, less than $1 \mathrm{~nm}$ thick and approximately $0.03-0.04 \mu \mathrm{m}$ long. In between these short fimbriae there were others which were approximately $1 \mathrm{~nm}$ thick and up to $0.4 \mu \mathrm{m}$ long (Fig.4).

\section{DISCUSSION}

Strains of C. suis haemagglutinated erythrocytes from a variety of animal species. In this character it is similar to C. pyogenes and $\mathrm{C}$. renale. These 3 species are also similar in that trypsinization does not influence the haemagglutination (Lindal \& Smyth 1982, Honda \& Yanagawa 1974).

The haemagglutination, the hydrophobic interaction chromatography, and the salt aggregation test all indicate a cell surface hydrophobicity (Lindal et al. 1981). Hydrophobic cells usually possess fimbriae or other surface proteins which might be of importance for the attachment of the bacteria to the epithelial cells, and may thus be of importance for the pathogenicity of the organisms (Beachey 1981, Duguid \& Old 1980). The heat sensitivity of the haemagglutination further implies the presence of surface proteins. Electron microscopy revealed the presence of fimbriae on the cells of all strains tested. The long fimbriae on 
cells of strain 8 were flexible and rather similar to those of strain 4, whereas the short fimbriae on cells of strain 8 seemed to be rather rigid. Whether they really are different has to be confirmed by immuno-electron-microscopy. The haemagglutinating activity of cells of strains 5 and 8 was identical, although the fimbriation of these cells appeared to be different.

The inhibitory effect of fetuin and glycoprotein on the haemagglutination supports the hypothesis of glycoconjugates as specific receptor sites for the attachment of $\mathrm{C}$. suis.

Ørskov et al. (1980) observed that some uropathogenic, fimbriated (F7) E. coli strains attached to cells but not to mucus, and suggested that mucus might act as a trap for some bacteria. Our observation that cells of $\mathrm{C}$. suis did not reach with mucin could mean that presence or absence of mucin is of importance for the establishment of an infection, provided that the same kind of mucin occurs in the urogenital tract and the bladder.

The low proportion of strains which were able to haemagglutinate porcine erythrocytes could be of importance for the pathogenesis, in that attachment of bacteria to erythrocytes might facilitate the phagocytosis of the bacteria and perhaps enhance cell destruction (Beachey 1981).

Our observations can be compared to similar studies of pyelonephritogenic E. coli for which it has been proposed that colonization of the periurethral area precedes an ascending infection (Stamey \& Sexton 1975). The colonization of preputium of male pigs with cells of $C$. suis is regarded to be the main event for the infection to occur (Jones \& Dagnall 1984). Instead of the traumatic way of colonization suggested by Biering-Sфrensen (1967), the heavily fimbriated strains could attach and colonize the urethral region during mating of the sows.

An anti-fimbrial serum reduced the attachment rate of $C$. renale cells to the mucous membrane of the urin bladder of mice (Honda \& Yanagawa 1978), thus stressing the importance of fimbriae for attachment and colonization.

Colonization and the subsequent ascending infection is dependent on the presence of specific receptors on the uroepithelial cells. An urethral infection occurs by means of retrograde ascent into an area of turbulent flow and/or by mild reflux. Adhesion of bacteria may subsequently induce uretheritis, and is followed by an increased pressure in the urether and pelvis renis with a further development of pyelonephritis (Latham \& Stamm 1984). 
The production of urease appears to be a very important character of uropathogenic bacteria (Reid et al. 1984). Urease might be responsible for a disruption of the urothelium, probably because of its ability to alkalinize the urine. This disruption enables the bacteria to invade tissues where the toxic products could cause further damages (Musher et al. 1975). The ability of C. suis to attach to cells in a monolayer in the presence of urea has been described previously (Larsen 1970). Furthermore, it should be emphasized that a $\mathrm{pH}$ dependent adhesion has been demonstrated also for C. renale (Takai et al. 1980).

The results of the present study show that C. suis possesses many of the characteristics of other uropathogenic bacteria, and we therefore suggest that cells of $\mathrm{C}$. suis establish infection in a similar way as do cells of $\mathrm{C}$. renale and $\mathrm{C}$. pyogenes.

\section{ACKNOWLEDGEMENTS}

The very skilful technical assistance of Merete Mørk Jensen is greatly appreciated. We also thank Ebert Müller for the photographic work, and Jane Røken for the typing of the manuscript.

\section{REFERENCES}

Beachey, E. H.: Bacterial adherence: Adhesion-receptor interactions mediating the attachment of bacteria to mucosal surfaces. J. infect. Dis. 1981, 143, 325-345.

Biering-Sфrensen, $U .:$ Om den almindelige forekomst af cystitis og pyelonephritis hos søer. (On the occurrence of cystitis and pyelonephritis in sows). Medlemsbl. danske Dyrlægeforen. 1967, 50, 1103-1107.

Van den Bosch, J. F., V. Verboom-Sohmner, P. Postma, J. de Graaff \& D. M. MacLaren: Mannose-sensitive and mannose-resistant adherence to human uroepithelial cells and urinary virulence of Escherichia coli. Infect. Immun. 1980, 29, 226-233.

Duguid, J. P., I. W. Smith, G. Dempster \& P. N. Edmunds: Non-flagellar filamentous appendages ("fimbriae") and haemagglutinating activity in Bacterium coli. J. Path. Bact. 1955, 70, 335-358.

Duguid, J.P.\& R. R. Gillies: Fimbriae and adhesive properties of dysentery bacilli. J. Path. Bact. 1957, 74, 497-411.

Duguid, J. P. \& D. C. Old: Adhesion properties of Enterobacteriaceae. In: Beachey, E. H. (ed.). Bacterial adherence, receptors and recognition. Series B Vol. 6. Chapman and Hall, London, New York, p. 185-217.

Faris, A., M. Lindahl \& T. Wadström: High surface hydrophobicity of haemagglutinating Vibrio cholerae and other Vibrio. Curr. Microbiol. 1982, 7, 357-362. 
Honda, E. \& R. Yanagawa: Agglutination of trypsinized sheep erythrocytes by the pili of Corynebacterium renale. Infect. Immun. $1974,10,1426-1432$.

Honda, E. \& R. Yanagawa: Attachment of Corynebacterium renale to tissue culture cells by the pili. Amer. J. vet. Res. 1975, 36, 1663 -1666 .

Honda, E. \& R. Yanagawa: Pili-mediated attachment of Corynebacterium renale to mucous membrane of urinary bladder of mice. Amer. J. vet. Res. 1978, 39, 155-159.

Hovind-Hougen, K. \& A. Birch-Andersen: Electron microscopy of endoflagella and microtubules in Treponema Reiter. Acta path. microbiol. scand. $1971,79 B, 37-50$.

Jones, G. W.: The attachment of bacteria to the surface of animal cells. In J. L. Reissig (ed.). Microbial interactions. Chapman and Hall, London 1977, p. 139-176.

Jones, J. E. T. \& G. J. R. Dagnall: The carriage of Corynebacterium suis in male pigs. J. Hyg. (Camb.) 1984, 000, 381-388.

Källenius, G., S. B. Svenson, H. Hultberg, R. Möllby, J. Winberg \& J. A. Roberts: P-fimbriae of pyelonephritogenic Eschericia coli: Significance for reflux and renal scarring - A hypothesis. Infection $1983,11,73-76$.

Larsen, J. L.: Corynebacterium suis infections in swine. Nord. Vet.Med. $1970,22,422-431$.

Latham, R.H. \& W. E. Stamm: Role of fimbriated Eschericia coli in urinary tract infections in adult women: Correlation with localization studies. J. infect. Dis. 1984, 149, 835-848.

Lindahl, M., A. Faris, T. Wadström \& S. Hjertén: A new test based on "salting out" to measure relative surface hydrophobicity of bacterial cells. Biochim. Biophys. Acta 1981, 677, 471-476.

Lindahl, E. \& J. Smyth: Haemagglutinating activity in Corynebacterium pyogenes. Curr. Microbiol. 1982, 7, 113-118.

Mandel, I. D.: Oral secretions and fluid flow. J. dent. Res. 1976, 55 (Suppl.), 22-37.

Musher, D. M., .D P. Griffith, D. Yawn \& R. D. Rossen: Role of urease in pyelonephritis resulting from urinary tract infection with Proteus. J. infect. Dis. 1975, 131, 177-181.

Reid, G., M. L. Zorzitto, A. W. Bruce, M. A. S. Jewett, R. C. Y. Chan \& $J$. W. Costerton: Pathogenesis of urinary tract infection in the elderly: The role of bacterial adherence to uroepithelial cells. Curr. Microbiol. 1984, 11, 67-72.

Sato, H., R. Yanagawa \& H. Fukuyama: Adhesion of Corynebacterium renale, Corynebacterium pilosum and Corynebacterium cystitidis to bovine urinary bladder epithelial cells of various ages and levels of differentiation. Infect. Immun. 1982, 36, 12421245.

Stamey, T. A. \& C. C. Sexton: The role of vaginal colonization with Enterobacteriaceae in recurrent urinary infections. J. Urol. $1975,113,214-217$. 
Takai, S., R. Yanagawa \& Y. Kitamura: $\mathrm{pH}$-Dependent adhesion of piliated Corynebacterium renale to bovine bladder epithelial cells. Infect. Immun. 1980, 28, 669-674.

Ørskov, I., F. Ørskov \& A. Birch-Andersen: Comparison of Escherichia coli fimbrial antigen F7 with Type 1 fimbriae. Infect. Immun. 1980, 27, 657-666.

\section{SAMMENDRAG}

Hæmagglutinerende og hydrofobe egenskaber hos Corynebacterium (Eubacterium) suis.

Corynebacterium (Eubacterium) suis stammer isoleret fra søer og ornesæd hæmagglutinerede erythrocytter fra kalv, marsvin, høns, svin og menneske. Hæmagglutinationsevnen blev ikke hæmmet af Dmannose, L-fucose eller D-galactose. Hydrofobicitet målt ved saltaggregeringstest $\left(0,1-0,9 \mathrm{~mol} / 1\left(\mathrm{NH}_{4}\right)_{2} \mathrm{SO}_{4}\right)$ og ved interaktionskromatografi (90\% tilbageholdelse i octyl-sepharose) i forbindelse med hæmagglutination af erythrocytter indikerede tilstedeværelse af fimbriae. De hæmagglutinerende og hydrofobe egenskaber var varmelabile $\left(60^{\circ} \mathrm{C}\right.$ i $\left.10 \mathrm{~min}\right)$, hvilket tydede på, at de var forårsaget af proteiner. To typer af fimbriering blev påvist ved elektronmikroskopi. Fetuin og glycoprotein hæmmede hæmagglutinationen, medens porcinmucin var uden effekt. Dette kan tyde på, at forgrenede glycoproteiner kan være receptorer for disse fimbriae.

Med basis i erfaringer for andre bakterier, der er involveret $\mathrm{i}$ pyelonephritis, diskuteres patogenetiske aspekter ved dette syndrom.

\section{(Received July 17, 1986).}

Reprints may be requested from: Jens Laurits Larsen, the Department of Hygiene and Microbiology, Royal Veterinary and Agricultural University, 13 Bülowsvej, DK-1870 Frederiksberg C, Denmark. 